\title{
Action of Fractionated Moringa oleifera Lam Leaf Extracts on Multidrug Resistant Pseudomonas aeruginosa Strains
}

\author{
Eremwanarue Aibuedefe Osagie ${ }^{1,3, *}$, Erhauyi Osayemwenre ${ }^{2}$, Nwawuba Stanley Udogadi ${ }^{4}$, \\ Shittu Hakeem Olalekan ${ }^{1}$ \\ ${ }^{1}$ Department of Plant Biology and Biotechnology, University of Benin, PMB, 1090, Ugbowo, Benin City, Nigeria. \\ ${ }^{2}$ Department of Pharmaceutical Chemistry, University of Benin, PMB, 1090, Ugbowo, Benin City, Nigeria. \\ ${ }^{3}$ Lahor Research Laboratories and Diagnostics Centre, 121, Old Benin-Agbor Road, Benin City, Nigeria. \\ ${ }^{4}$ Centre for Forensic Programmes and DNA Studies, University of Benin, PMB, 1090, Ugbowo, Benin City, Nigeria.
}

\begin{abstract}
How to cite this paper: Eremwanarue Aibuedefe Osagie, Erhauyi Osayemwenre, Nwawuba Stanley Udogadi, Shittu Hakeem Olalekan. (2021) Action of Fractionated Moringa oleifera Lam Leaf Extracts on Multidrug Resistant Pseudomonas aeruginosa Strains. International Journal of Clinical and Experimental Medicine Research, 5(3), 316-329.

DOI: 10.26855/ijcemr.2021.07.014
\end{abstract}

Received: April 23, 2021

Accepted: May 22, 2021

Published: June 23, 2021

*Corresponding author: Eremwanarue Aibuedefe Osagie, Department of Plant Biology and Biotechnology, University of Benin, PMB, 1090, Ugbowo, Benin City, Nigeria; Lahor Research Laboratories and Diagnostics Centre, 121, Old Benin-Agbor Road, Benin City, Nigeria.

Email:

eremwanarueaibuedefe@yahoo.com

\begin{abstract}
Pseudomonas aeruginosa is an opportunistic pathogen with the potential to cause serious surgical wound infections and remains a major problem especially in developing countries of the world. This has led to investigating antimicrobial actions of fractionated Moringa oleifera leaf extract on multidrug Pseudomonas aeruginosa strains. Isolation of $P$. aeruginosa strains from post-surgical wound in two locations used for the study, antibiotics susceptibility testing, qualitative and quantitative phytochemical screening were carried out using standard procedures followed by antibacterial testing of the different $M$. oleifera leaf extracts on selected multidrug resistant isolates. The results showed that 99 (35\%) of patients studied had wound infection out of the total 284 samples collected. Thirty-four (54.8\%) P. aeruginosa strains were found to show multidrug resistant ability from both locations studied. Qualitative analysis of phytoconstituents revealed the presence of flavonoid, phenol, saponins, steriods, tannin and terpenoids. Quantitative analysis showed that the different phytochemical recorded varying amount. Antibacterial assay results revealed that $M$. oleifera leaf n-hexane extract exhibited highest antibacterial activity against $P$. aeruginosa strain NAPCC-1 followed by methanol and aqueous methanol all at a concentration of $100 \mathrm{mg} / \mathrm{ml}$ while aqueous methanol best inhibited $P$. aeruginosa strain KAR12 growth followed by methanol then n-hexane extract. The varying effect could be attributed to the presence of phytochemicals in the different $M$. oleifera leaf extracts. The result of this study has shown the potentials of $M$. oleifera extracts as antibacterial agent by inhibiting the growth of the test organisms isolated from post-surgical wound infection.
\end{abstract}

\section{Keywords}

Pseudomonas aeruginosa, Moringa oleifera, wound swabs, Nosocomial infections

\section{Introduction}

Phytomedicine in Africa and other continents of the world has been utilized from time immemorial to treat various diseases way back before the beginning of modern medicine. The use of medicinal plants is still broadly em- 
ployed in many parts of the world particularly in areas where the populace does not have access to modern medicine [1]. Generally, plants have been reported to enclose large varieties of chemical substances that hold vital defensive and remedial therapies [2, 3]. About $80 \%$ of the population from urbanized countries uses conventional medicine, which have compounds derived from medicinal plants [4]. Despite the presence of diverse approaches to drug breakthrough, plants still remain the key pool of natural medicine [5, 6].

Moringa oleifera is a vastly cherished plant and dispersed in many countries of the tropics and subtropics, well-known for its wide range of medicinal properties. It has a remarkable variety of medicinal uses with high nutritional value. Different parts of this plant enclose a profile of vital minerals, and are excellent source of protein, vitamins, $\beta$-carotene, amino acids and different phenolics [7].

Moringa plant provides a rich and uncommon mixture of zeatin, quercetin, kaempferol and many other phytochemicals. Various parts of the plant such as the leaves, roots, seed, bark, fruit, flowers and immature pods are utilized as cardiac, circulatory stimulants and well possess anti-tumour, anti-pyretic, anti-epileptic, anti-inflammatory, anti-ulcer properties [8]. Other important medicinal properties of the plant include antihypertensive, cholesterol lowering [9], antioxidant, anti-diabetic, antibacterial and antifungal activities [10]. The crushed seeds were conventionally utilized for water purification purpose by flocculating Gram-positive and Gram-negative bacterial cells [11, 12], used as a less expensive bio absorbent for the elimination of heavy metals [13]. Extracts of roots and seeds have shown to have antimicrobial property and juices from the leaves have been employed in treating eye infections and other bacterial infections due to its phytochemical composition.

Pseudomonas aeruginosa is an opportunistic pathogen causing severe healthcare-related infections particularly in immune-compromised post-surgical wound patients [14]. Generally, surgical wounds through the repression of body defense system become appropriate spot for microbial reproduction. Hence, $P$. aeruginosa infection in post-surgical wound patients is common and is seen as one of the leading serious life-threatening situations in surgical operation units [15]. Furthermore, as a result of the resistance of these microbes to a vast collection of regularly used antibiotics in recent years, handling infections caused by them has been dreary and has resulted in enhanced mortality [16]. The difficulty in treating P. aeruginosa infection is because of its acquired and intrinsic resistance to diverse antibiotics caused by many mechanisms such as low outer membrane permeableness, over expression of efflux pump and protein modifications has led to increased use of plants as substitute for treatment of some bacterial infections [17]. In recent years, interest has grown in the utilization of what has come to be known as "multipurpose" plants; one of such plants is Moringa oleifera Lam, the most widely cultivated species of a monogeneric family Moringaceae [18]. Despite the array of uses Moringa tree are employed, scanty literature is available on the antibacterial action of fractionated Moringa oleifera leaf extract against multiple drug resistant Pseudomonas aeruginosa strains isolated from post-surgical wound infections.

\section{Materials and Methods}

\subsection{Collection, authentication and processing of plant materials}

The fresh leaf of M. oleifera was collected from Doctor's Quarters, University of Benin Teaching Hospital, Egor Local Government Area, Edo State, Nigeria. The plant materials were identified and authenticated by a Botanist at the Department of Plant Biology and Biotechnology, University of Benin, Nigeria. Confirmation of plant taxonomic identity was done by comparison with voucher specimens kept at the Herbarium of the Department of Plant Biology and Biotechnology, University of Benin. The plant materials were air-dried in the laboratory at room temperature for 15 days [19]. The dried leaves were grounded into powdered form, using a mortar and pestle, and stored for future use.

\subsection{Preparation of Moringa oleifera leaf extracts}

The powdered plant material of five hundred grams (500 g) was macerated in two point five liters of methanol $(2.5 \mathrm{~L})$ at room temperature for three (3) days [8]. The percolates were filtered with Whatman's No 1 filter paper. The extract was concentrated to dryness using a rotary evaporator at reduced pressure. The dried extract was weighed and the percentage yield calculated. The extract was stored in an air-tight container and kept in the refrigerator at $4^{\circ} \mathrm{C}$ until further experiment [20].

\subsubsection{Solvent-Solvent Extraction}

Solvent-Solvent Extraction (Pre-Fractionation/Partitioning) of the crude methanol extract ( $25 \mathrm{~g}$ ) was dissolved in $100 \mathrm{~mL}$ of methanol-water (4:1) and extracted successively with n-Hexane [21]. Briefly, $500 \mathrm{~mL}$ of n-Hexane was added to the methanol extract in a separating funnel. The mixture was slightly agitated and the pressure accumu- 
lated in the funnel was released by opening the tap. The mixture was allowed to stand for a few minutes and the hexane layer was collected. The recovered methanol extract was again extracted with $500 \mathrm{~mL}$ of n-hexane and separated. This procedure was repeated until a total of $2 \mathrm{~L}$ of n-hexane was used and the hexane layer became clear. The n-hexane portions were combined and evaporated to dryness. The various fractions were concentrated to dryness, weighed and the percentage yields calculated.

\subsubsection{Phytochemical Analysis}

Phytochemical screening was performed to identify phytochemicals in the Methanol, n-hexane and aqueous methanolic extract of Moringa oleifera leaf used in this study. The phytochemicals were detected by colour tests. Each extract was tested for the presence of alkaloids, anthroquinines, flavonoids, glycosides, phenols, saponins, sterols and tannins using different known methods. The tests were performed in triplicates to ensure accurate results.

\subsubsection{Detection of alkaloids}

Three methods were used for the detection of alkaloids with some modifications.

\section{i. Dragendorff's test}

There drops of Dragendorff's reagent was added in $1 \mathrm{ml}$ of extract filtrate. Formation of orange-brown precipitate indicates the occurrence of alkaloids [22].

\section{ii. Mayer's test}

To a $1 \mathrm{ml}$ of test extract filtrate in a watch glass, two few drops of Mayer's reagent were added. Formation of cream-colored precipitate shows the presence of alkaloids [23].

\section{iii. Wager's test}

The occurrence of alkaloids was tested using method reported by [23]. $10 \mathrm{ml}$ of the extract were evaporated to dryness. Two $\mathrm{ml}$ of $2 \% \mathrm{HCL}$ acid were added to the dry residue. Two drops of Wagner's reagent were added to the solution. Reddish brown precipitate indicates the presence of alkaloids.

\subsubsection{Detection of flavonoids}

The test was based on method described by [24]. Few drops of $\mathrm{NaOH}$ were added to two ml of the extract and intense yellow color appeared. Few drops of dilute HCL were added and the solution turned to colorless as indicator of presence of flavonoids.

\subsubsection{Detection of saponins}

Five milliners of distilled water was added to $1 \mathrm{ml}$ of Moringa oleifera leaf extract in a test tube. The solution was then shaken vigorously and stable persistent froth indicates the presence of saponins [25].

\subsubsection{Detection of phenols}

Two drops of ferric chloride solution was added to $1 \mathrm{ml}$ of extract. Formation of bluish black colour indicates the presence of phenol [25].

\subsubsection{Detection of steroids}

The test was performed based on method described by [26]. Two ml concentrated sulphuric acid were added to 1 $\mathrm{ml}$ of the extract. Formation of red precipitate indicates the presence of sterols.

\subsubsection{Detection of tannins}

Two drops of $10 \%$ lead acetate were added to $2 \mathrm{ml}$ of each extract. The appearance of white precipitate indicates the presence of tannins as described by [27].

\subsubsection{Detection of terpenoids}

Two milliners of chloroform and $1 \mathrm{ml}$ concentrated tetraoxosulphate (VI) acid was added to $1 \mathrm{ml}$ of extract to form a layer. The presence of a reddish brown colouration at the interface shows the occurrence of terpenoids [28].

\subsubsection{Detection of Glycosides}

Few drops of glacial acetic acid and ferric chloride was added to $1 \mathrm{ml}$ of each extract, 3 drops of concentration sulphuric acid were added. The appearance of blue-green colour indicates the presence of glycosides [27].

\subsubsection{Detection of anthraquinones}

One milliliter of extracts was boiled in $10 \% \mathrm{HCl}$ for 5 mins and the filtrate was allowed to cool. The filtrate were treated with equal volume of $\mathrm{CHCl} 3$ with few drops of $10 \%$ ammonia was added to the $2 \mathrm{ml}$ filtrate. The formation of rose-pink colour implies the presence of anthraquinones [29]. 


\subsection{Quantitative phytochemical analysis of Moringa oleifera extract}

\subsubsection{Determination of total phenol}

Total phenol contents in the extracts were determined by the method described by [30]. The extract solution (0.5 $\mathrm{mL}$ ) with a concentration of $1,000 \mu \mathrm{g} / \mathrm{mL}$ was added to $4.5 \mathrm{~mL}$ of deionized distilled water and $0.5 \mathrm{~mL}$ of Folin Ciocalteu's reagent (previously diluted with water 1:10, v/v) which was then added to the solution. After mixing the tubes, they were maintained at room temperature for 5 minutes followed by the addition of $5 \mathrm{~mL}$ of $7 \%$ sodium carbonate and $2 \mathrm{~mL}$ of deionized distilled water. After mixing the samples, the samples were incubated for $90 \mathrm{mi}-$ nutes at room temperature. The absorbance was measured by spectrophotometer at $750 \mathrm{~nm}$. The total phenolic content was expressed as milligrams of gallic acid equivalents (GAE) per gram of extract (mg GAE/g extract). The standard curve was prepared by gallic acid in six different concentrations (12.5, 25, 50, 75, 100 and $150 \mathrm{mg} / \mathrm{L})$.

\subsubsection{Determination of total flavonoid}

Total flavonoid contents were estimated using the method described by [31]. Briefly, $0.5 \mathrm{~mL}$ of extract sample (1 $\mathrm{mg} / \mathrm{mL}$ ) was mixed with $1.5 \mathrm{~mL}$ of methanol and then, $0.1 \mathrm{~mL}$ of $10 \%$ aluminium chloride was added, followed by $0.1 \mathrm{~mL}$ of $1 \mathrm{M}$ potassium acetate and $2.8 \mathrm{~mL}$ of distilled water. The mixture was incubated at room temperature for 30 minutes. The absorbance was measured by a spectrophotometer at $415 \mathrm{~nm}$. The results were expressed as milligrams quercetin equivalents (QE) per gram of extract (mg QE/g extract). The standard curve was prepared by quercetin in six different concentrations (12.5, 25, 50, 75, 100 and $150 \mathrm{mg} / \mathrm{L})$.

\subsubsection{Determination of total tannin content}

The tannins were determined by Folin-Ciocalteu method as previously described by [31] with slight modification. About $0.5 \mathrm{ml}$ of the sample extract $(1 \mathrm{mg} / \mathrm{mL})$ was added to a volumetric flask $(10 \mathrm{~mL})$ containing $7.5 \mathrm{~mL}$ of distilled water and $0.5 \mathrm{~mL}$ of Folin-Ciocalteu phenol reagent, $1 \mathrm{~mL}$ of $35 \%$ sodium carbonate solution and dilute to 10 $\mathrm{ml}$ with distilled water. The mixture was shaken well and kept at room temperature for $30 \mathrm{~min}$. a set of reference standard solutions of tannic acid $(20,40,60,80,100 \mu \mathrm{g} / \mathrm{mL})$ were prepared in the same manner as described earlier. Absorbance for test and standard solutions were measured against the blank at $700 \mathrm{~nm}$ with an UV/ Visible spectrophotometer. The estimation of the tannin content was carried out in triplicate. The tannin content was expressed in terms of mg of tannic acid equivalents/g of dried sample.

\subsubsection{Determination of total saponin content}

The saponin content of the samples was determined by double extraction gravimetric method described by [32]. A measured weight $(0.5 \mathrm{~g})$ of the powdered sample was mixed with $5 \mathrm{~mL}$ of $20 \%$ aqueous ethanol solution in a flask. The mixture was heated with periodic agitation in water bath for 90 minutes at $55^{\circ} \mathrm{C}$; it was then filtered through Whatman filter paper (No 42). The extract was transferred to a separating funnel where $20 \mathrm{~mL}$ of diethyl ether was added and shaken vigorously. Re-extraction by partitioning was repeated twice (each with $20 \mathrm{~mL}$ diethyl ether) until the aqueous layer become clear in colour. The ether layer was discarded and the saponins in the aqueous layer were extracted $3 \times$ (each with $20 \mathrm{~mL}$ ) of normal butanol. The combined butanol extracts were washed with $5 \%$ aqueous sodium chloride ( $\mathrm{NaCl})$ solution and evaporated to dryness in a pre-weighed evaporation dish. It was dried at $60^{\circ} \mathrm{C}$ in the oven and reweighed after cooling in a dessicator. The process was repeated one more time to get an average. Saponin content was determined by difference and calculated as a percentage of the original sample thus: Percentage saponin $=\mathrm{W} 2-\mathrm{W} 1 /$ weight of sample $\mathrm{x} 100$

Where: W1 = Weight of evaporating dish, W2 = Weight of evaporating dish + sample

\subsubsection{Determination of total terpenoid content}

This protocol describes a rapid, small-scale, high-throughput assay for approximating the total terpenoids content in plant tissue using a monoterpeneas standard reagent with conc. sulfuric acid. All estimation has been done spectroscopically at $538 \mathrm{~nm}$. In brief, one point five microliters of chloroform was added to $200 \mu \mathrm{l}$ of sample solution $(10 \mathrm{mg} / \mathrm{mL})$. The sample mixture was vortexed thoroughly and allowed to stand for 3 minutes then $100 \mu l$ Conc. Sulfuric acid (H2SO4) was added to each $2 \mathrm{ml}$ microcentrifuge tube. The assay tube was incubated at room temperature for $1.5 \mathrm{~h}$ in the dark but for standard solution, (Thymol) incubation was not more than 5 minutes. At the end of incubation, a reddish-brown precipitation was formed in each assay microcentrifuge tube which was carefully and gently decanted without disturbing the precipitation. $1.5 \mathrm{ml}$ of $95 \%$ (Vol/Vol) methanol was added to the mixture and vortex thoroughly until all the precipitation was dissolved in the methanol completely. The sample was then transferred from assay tube to Colorimetric cuvette. Methanol [95\% (Vol/Vol)] was used as blank] and absorbance was read at $538 \mathrm{~nm}$. Total terpenoids concentration of unknown plant sample was calculated as Thymol 
equivalents using the regression equation of thymol standard curve.

\subsubsection{Estimation of total Steroid content}

One milliliter of test extract of steroid solution $(1 \mathrm{mg} / \mathrm{mL})$ was transferred into $10 \mathrm{ml}$ volumetric flasks. Sulphuric acid (4N, $2 \mathrm{ml})$ and iron (III) chloride ( $0.5 \% \mathrm{w} / \mathrm{v}, 2 \mathrm{ml})$, were added, followed by potassium hexacyanoferrate (III) solution $(0.5 \% \mathrm{w} / \mathrm{v}, 0.5 \mathrm{ml})$. The mixture was heated in a water-bath maintained at $70^{\circ} \mathrm{C}$ for 30 minutes with occasional shaking and diluted to the mark with distilled water. The absorbance was measured at $780 \mathrm{~nm}$ against the reagent blank. The quantity in milligram of the steroid in the $10 \mathrm{~mL}$ aliquot of the test solution is given by the expression; At / As X Cs

Where At = absorbance of the test solution; As = absorbance of the standard solution; Cs = quantity, in milligram, of the reference substance in the $10 \mathrm{ml}$ aliquot of the standard solution. The quantity of the steroid in the substance was calculated on the basis of the aliquot taken for the determination and from the declared content of the steroid in the appropriate reference substance. Cholesterol was used as the reference substance.

\subsubsection{Test organism sample collection}

A total of 284 random swab sampling of post-operative surgical wound patients was collected from both outpatient and inpatient in University of Benin Teaching Hospital (UBTH) and Central Hospital Benin (CHB), Benin City.

\subsubsection{Ethical clearance}

Approval was obtained from the University of Benin Teaching Hospital and Central Hospital, ethical committee and all patients gave their support after being educated of the objectives of study.

\subsubsection{Bacteriological procedures/identification of isolates}

Swab samples were aseptically inoculated onto MacConkey, Blood and Nutrient agar and incubated aerobically at $37^{\circ} \mathrm{C}$ for 24 hours and checked for colony growth. Isolates were screened for Pseudomonas aeruginosa. All specimens were processed at Lahor research Laboratories, Benin City, Nigeria using standard microbiological methods. All isolates were identified using conventional techniques [33].

\subsubsection{Antibiotic susceptibility testing}

The susceptibility of bacterial isolates to commonly used antibiotic was determined by the Kirby-Bauer disk diffusion method for in vitro antibiotic sensitivity as described by CLSI (2011) against the following antibiotics for

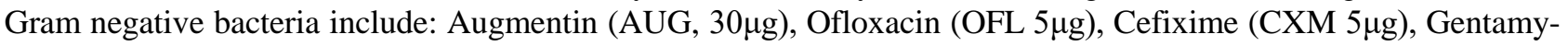

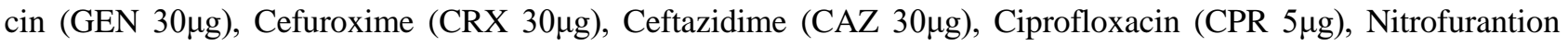
(NIT 300 $\mu$ g). The concentrations of antibiotics susceptibility and explanation of zones of inhibition were in accordance to Performance Standards for antimicrobial disk susceptibility tests of Clinical and Laboratory Standards Institute.

\subsubsection{Standardization of Inoculum}

The inocula were prepared from the stock cultures, which were maintained on nutrient agar slant at $4^{\circ} \mathrm{C}$ and subcultured onto nutrient broth using a sterilized wire loop. The density of suspension inoculated onto the media for susceptibility test was determined by comparison with 0.5 McFarland standard of Barium sulphate solution [33].

\subsection{Screening of Moringa oleifera leaf extracts for antimicrobial activity}

Antibacterial activity of Moringa oleifera methanolic extracts and the different fractions were tested against the multidrug resistant Pseudomonas aeruginosa strains using the agar diffusion method. Mueller-Hinton agar medium was prepared, sterilized, cooled and poured into sterile petri-dishes to a depth of $4 \mathrm{~mm}$ about $20 \mathrm{ml} / \mathrm{plate}$ and was allowed to solidify. Overnight cultures of bacterial isolate were diluted with sterile normal saline to give inoculum size of $10^{6} \mathrm{cfu} / \mathrm{ml}$ which was used to flood the surface of the Mueller-Hinton agar media. It was then discarded and allowed to dry. Five wells of $6 \mathrm{~mm}$ in diameter each were aseptically bored using a sterile cork borer on each agar plate. The base of each well was filled with molten agar to seal the bottom and allowed to gel. Aliquot of $0.2 \mathrm{ml}$ of the extract with different concentrations $(100.00,50.00,25.00,12.50$ and $6.25 \mathrm{mg} / \mathrm{ml})$ was added to the different wells. The same procedure was applied to all extracts. The plates were left to allow for diffusion of extract before incubation at $37^{\circ} \mathrm{C}$ for 24 hours. The zones of inhibition (clearance) produced around the wells after incubation were observed, measured and recorded. 


\subsection{Determination of minimum inhibitory concentration}

The minimum inhibitory concentrations of the extracts of Moringa oleifera leaf was determined by two-fold serial dilution method as described by [34]. The stock concentration of $100.00 \mathrm{mg} / \mathrm{ml}$ of the extracts was double diluted separately to achieve different concentrations of 50.00, 25.00, 12.50 and $6.25 \mathrm{mg} / \mathrm{ml}$. Aliquot of $2 \mathrm{ml}$ of the crude extract in the desired concentration was introduced into tube one containing $2 \mathrm{ml}$ of distilled water and mixed thoroughly. The content $(2 \mathrm{ml})$ from tube one was transferred into tube two, it was also mixed thoroughly and $2 \mathrm{ml}$ of the content of tube two was also transferred into test tube three. The procedure was repeated for the remaining test tubes. Pre-diffusion period of 15 minutes was allowed before incubation, and the result recorded after the incubation period at $37^{\circ} \mathrm{C}$ for 24 hours.

\subsection{Statistical analysis}

The data from the experiment were analyzed with SPSS version 20.0 using one way analysis of variance (ANOVA) where there was significant difference, Duncan Multiple Range test was used to separate the mean. Chi-square was also used to test for significant difference. Graphical representation was done using Microsoft word. The results were expressed as mean \pm SEM (Standard error of mean).

\section{Results}

In the present study, two hundred and eighty-four (284) post-operative surgical wound swabs specimens from in and out patients were analyzed. Ninety-nine (35\%) of patients studied had wound infection. Sixty-two (62.6\%) $P$. aeruginosa were isolated from surgical wound infections and screened with eight routinely used antibiotics to identify multiple drug antibiotic resistant strains. Thirty-four (54.8\%) isolates showed multiple drug resistance ability. Based on the antibiotics susceptibility results obtained, most of the isolates screened showed high resistance to Ceftazidime, Augmentin, Cefixime and gentamicin (54.8\%) as is shown in Figure 1.

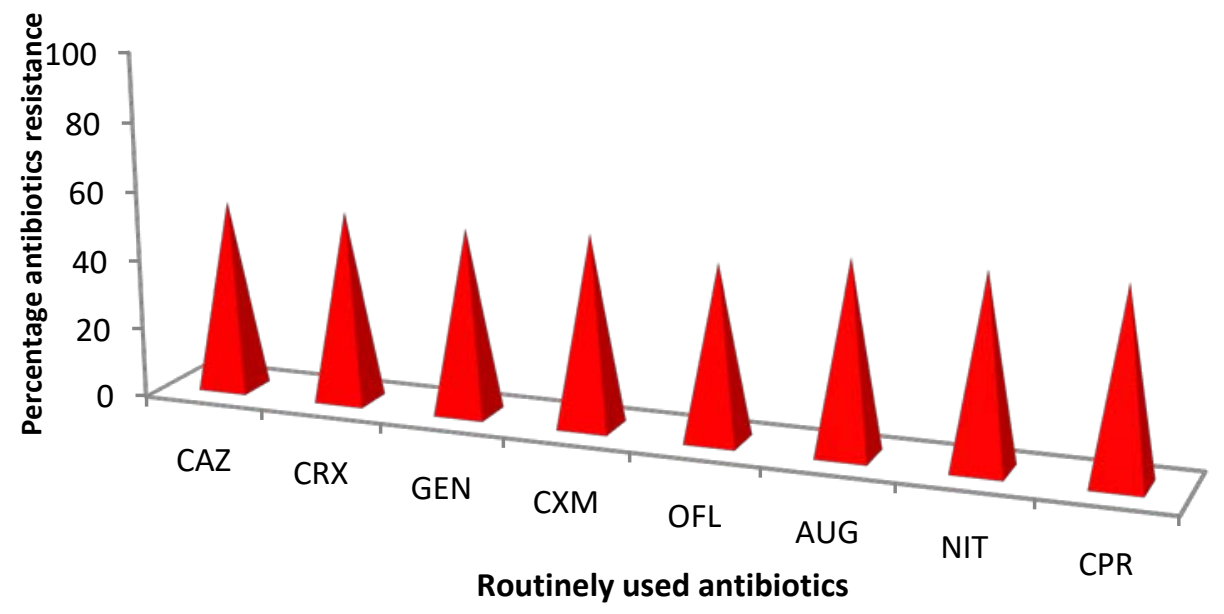

Figure 1. Antibiotics resistance pattern of $P$. aeruginosa strains. CAZ: Ceftazidime. CRX: Cefuroxime, GEN: Gentamicin, CXM: Cefixime, OFL: Ofloxacin, AUG: Augmentin, NIT: Nitrofuration, CPR: Ciprofloxacin.

Five hundred grams (500 g) of powered leaf of M. oleifera were extracted with two point five liters (2.5 L) of methanol and then evaporated to dryness. The extract yielded $26.5 \mathrm{~g}$ crude extract of methanol. Fractionation of crude methanol extract were carried out using n-Hexane and yielded $7.0 \mathrm{~g}$, the aqueous methanol extract were also evaporated to dryness and yielded $2.5 \mathrm{~g}$ (Table 1). Qualitative analysis of all extracts revealed the presence of six (6) phytochemical constituents out of the nine tested in methanol, 5 phytochemical present in aqueous methanol and n-hexane showed 2 phytochemicals as shown in Table 2. Quantitative analysis of the phtytoconstituent present revealed varying quantities of the phytochemicals screened (Table 3). 
Table 1. Dried extract yield of Moringa oleifera leaf

\begin{tabular}{cc}
\hline Moringa oleifera leaf Extract & Extract dried yield (grams) \\
\hline Methanol & 26.5 \\
n-Hexane fraction & $7.0 \mathrm{~g}$, \\
Aqueous methanol & $2.2 \mathrm{~g}$ \\
\hline
\end{tabular}

Table 2. Phytochemical screening of Moringa oleifera methanol, aqueous methanol and n-hexane leaf extract fractions

\begin{tabular}{cccc}
\hline Phytochemicals & Methanolic extracts & Aqueous methanolic fraction & n-Hexane fraction \\
\hline Alkaloids & - & - & - \\
Anthraquinone & - & - & - \\
Flavonoid & + & + & - \\
Glycoside & - & - & - \\
Phenol & + & + & - \\
Saponins & + & + & - \\
Steriods & + & - & + \\
Tannin & + & + & - \\
Terpenoids & + & + & + \\
\hline
\end{tabular}

Where + : indicate the presence of phytochemicals, - : indicate the absence of phytochemicals

Table 3. Quantitative phytochemical analysis of Moringa oleifera methanol leaf extracts

\begin{tabular}{ccc}
\hline Phytochemical & Standard & Total phytochemical Content \\
\hline Flavonoid & Quercetin & $202.845 \pm 53.88 \mathrm{mg} / \mathrm{g}$ \\
Phenol & Gallic Acid & $46.027 \pm 2.871 \mathrm{mg} / \mathrm{g}$ \\
Saponins* & - & $105.9 \pm 7.140 \mathrm{mg} / \mathrm{g}$ \\
Steriods & Cholesterol & $2.9 \pm 2.950 \mathrm{mg} / \mathrm{ml}$ \\
Tannin & Tannic acid & $69.473 \pm 4.686 \mathrm{mg} / \mathrm{g}$ \\
Terpenoids & Thymol & $33.83 \pm 29.796 \mathrm{mg} / \mathrm{ml}$ \\
\hline
\end{tabular}

*: Gravimetric Method; Values are mean \pm SEM

Testing of antibacterial activity of M. oleifera methanol leaf extracts on different strains of MDR Pseudomonas aeruginosa from Central Hospital Benin (CHB) showed that methanol extracts had inhibitory effect of various levels when compared with the control (standard reference) as shown in Table 4. Statistical analysis revealed that there was a high significant difference in the mean zone of inhibition at the different concentrations. The highest mean zone of inhibition of $22.67 \pm 1.45$ millimeters were seen in Pseudomonas aeruginosa strains R7-583 at 100 $\mathrm{mg} / \mathrm{ml}$ and the lowest acceptable mean zone of inhibition of $9.67 \pm 0.88$ millimeters at $25 \mathrm{mg} / \mathrm{ml}$ were observed in Pseudomonas aeruginosa strains PS2.

Table 4. Antibacterial activity of M. oleifera methanol leaf extracts against different MDR Pseudomonas aeruginosa strains from CHB

\begin{tabular}{|c|c|c|c|c|c|c|}
\hline Isolates & $\begin{array}{c}100 \mathrm{mg} / \mathrm{ml} \\
\bar{X} \pm S E\end{array}$ & $\begin{array}{c}50 \mathrm{mg} / \mathrm{ml} \\
\bar{X} \pm S E\end{array}$ & $\begin{array}{c}25 \mathrm{mg} / \mathrm{ml} \\
\bar{X} \pm S E\end{array}$ & $\begin{array}{c}12.5 \mathrm{mg} / \mathrm{ml} \\
\overline{\mathrm{X}} \pm \mathrm{SE}\end{array}$ & $\begin{array}{c}6.25 \mathrm{mg} / \mathrm{ml} \\
\bar{X} \pm S E\end{array}$ & P-value \\
\hline P. $a$ strain PS2 & $21.33^{\mathrm{a}} \pm 0.67$ & $12.0^{\mathrm{b}} \pm 1.16$ & $9.67^{\mathrm{c}} \pm 0.88$ & $1.00^{\mathrm{d}} \pm 0.00$ & $1.00^{\mathrm{d}} \pm 0.00$ & $\mathrm{P}<0.01$ \\
\hline P. $a$ strain NAPCC-1 & $18.33^{\mathrm{a}} \pm 1.67$ & $10.0^{\mathrm{b}} \pm 1.16$ & $8.00^{b} \pm 1.16$ & $1.00^{\mathrm{C}} \pm 0.00$ & $1.00^{\mathrm{C}} \pm 0.00$ & $\mathrm{P}<0.01$ \\
\hline P. $a$ strain DHS01 & $19.33^{\mathrm{a}} \pm 0.67$ & $4.67^{\mathrm{b}} \pm 1.45$ & $1.00^{c} \pm 0.00$ & $1.00^{\mathrm{C}} \pm 0.00$ & $1.00^{\mathrm{C}} \pm 0.00$ & $\mathrm{P}<0.01$ \\
\hline P. $a$ strain AR442 & $10.0^{\mathrm{a}} \pm 2.89$ & $1.00^{\mathrm{b}} \pm 0.00$ & $1.00^{\mathrm{b}} \pm 0.00$ & $1.00^{\mathrm{b}} \pm 0.00$ & $1.00^{\mathrm{b}} \pm 0.00$ & $\mathrm{P}<0.01$ \\
\hline P. $a$ strain R7-520-1 & $24.67^{\mathrm{a}} \pm 0.88$ & $12.33^{\mathrm{b}} \pm 1.45$ & $12.0^{\mathrm{b}} \pm 1.16$ & $1.00^{\mathrm{C}} \pm 0.00$ & $1.00^{\mathrm{C}} \pm 0.00$ & $\mathrm{P}<0.01$ \\
\hline P. $a$ strain H25883 & $21.67^{\mathrm{a}} \pm 1.67$ & $6.33^{\mathrm{b}} \pm 0.88$ & $6.00^{\mathrm{b}} \pm 1.16$ & $1.00^{\mathrm{C}} \pm 0.00$ & $1.00^{\mathrm{C}} \pm 0.00$ & $\mathrm{P}<0.01$ \\
\hline P. $a$ strain PA-VAP-2 & $13.67^{\mathrm{a}} \pm 2.03$ & $1.00^{\mathrm{b}} \pm 0.00$ & $1.00^{\mathrm{b}} \pm 0.00$ & $1.00^{\mathrm{b}} \pm 0.00$ & $1.00^{\mathrm{b}} \pm 0.00$ & $\mathrm{P}<0.01$ \\
\hline P. $a$ strain R7-583 & $22.67^{\mathrm{a}} \pm 1.45$ & $1.00^{\mathrm{b}} \pm 0.00$ & $1.00^{\mathrm{b}} \pm 0.00$ & $1.00^{\mathrm{b}} \pm 0.00$ & $1.00^{\mathrm{b}} \pm 0.00$ & $\mathrm{P}<0.01$ \\
\hline P. $a$ strain PA006 & $10.00^{\mathrm{a}} \pm 2.89$ & $1.00^{\mathrm{b}} \pm 0.00$ & $1.00^{\mathrm{b}} \pm 0.00$ & $1.00^{\mathrm{b}} \pm 0.00$ & $1.00^{\mathrm{b}} \pm 0.00$ & $\mathrm{P}<0.01$ \\
\hline P. $a$ strain $\mathrm{S} 2 \mathrm{H} 16$ & $15.0^{\mathrm{a}} \pm 2.89$ & $3.67^{\mathrm{b}} \pm 0.88$ & $3.67^{\mathrm{b}} \pm 0.88$ & $1.00^{\mathrm{C}} \pm 0.00$ & $1.00^{\mathrm{C}} \pm 0.00$ & $\mathrm{P}<0.01$ \\
\hline P. $a$ strain KAR21 & $10.0^{\mathrm{a}} \pm 0.00$ & $1.00^{\mathrm{b}} \pm 0.00$ & $1.00^{\mathrm{b}} \pm 0.00$ & $1.00^{\mathrm{b}} \pm 0.00$ & $1.00^{\mathrm{b}} \pm 0.00$ & $\mathrm{P}<0.01$ \\
\hline P. $a$ strain D2 & $20.67^{\mathrm{a}} \pm 1.76$ & $7.33^{\mathrm{b}} \pm 1.20$ & $3.67^{\mathrm{c}} \pm 0.88$ & $1.00^{\mathrm{C}} \pm 0.00$ & $1.00^{\mathrm{C}} \pm 0.00$ & $\mathrm{P}<0.001$ \\
\hline
\end{tabular}

Similar letters indicate means that are not significantly different $(\mathrm{P}>0.05), \mathrm{P}<0.01$-Highly significantly different, $\mathrm{P}<0.001$ - Very highly significantly different. Values are mean \pm SEM. Reading of significance is row. 
Antibacterial activity of M. oleifera methanol leaf extracts on different strains of MDR Pseudomonas aeruginosa from University of Benin Teaching Hospital (UBTH) revealed that methanol extracts had inhibitory effect of various levels when compared with the control as shown in Table 5. Statistical analysis showed that there was a high significant difference in the mean zone of inhibition at the different concentrations with the highest mean zone of inhibition of $32.33 \pm 1.45$ millimeters were seen in Pseudomonas aeruginosa strains Iraq.PA-9 at $100 \mathrm{mg} / \mathrm{ml}$ and the lowest acceptable mean zone of inhibition of $12.00 \pm 1.67$ millimeters at $25 \mathrm{mg} / \mathrm{ml}$ were observed in $P$. aeruginosa strains R8-768-1 followed by $P$. aeruginosa strains KAR21 and P. aeruginosa strains Iraq.PA-9 with $12.33 \pm$ 1.20 millimeters respectively.

Table 5. Antibacterial activity of M. oleifera methanol leaf extracts against different MDR Pseudomonas aeruginosa strains from UBTH

\begin{tabular}{|c|c|c|c|c|c|c|}
\hline Isolates & $\begin{array}{c}100 \mathrm{mg} / \mathrm{ml} \\
\overline{\mathrm{X}} \pm \mathrm{SE}\end{array}$ & $\begin{array}{c}50 \mathrm{mg} / \mathrm{ml} \\
\bar{X} \pm S E\end{array}$ & $\begin{array}{c}25 \mathrm{mg} / \mathrm{ml} \\
\overline{\mathrm{X}} \pm \mathrm{SE}\end{array}$ & $\begin{array}{c}12.5 \mathrm{mg} / \mathrm{ml} \\
\overline{\mathrm{X}} \pm \mathrm{SE}\end{array}$ & $\begin{array}{c}6.25 \mathrm{mg} / \mathrm{ml} \\
\bar{X} \pm S E\end{array}$ & P-value \\
\hline P. $a$ strain SWD & $12.00^{\mathrm{a}} \pm 1.16$ & $6.33^{b} \pm 0.88$ & $3.67^{\mathrm{C}} \pm 0.88$ & $1.33^{\mathrm{d}} \pm 0.00$ & $1.00^{\mathrm{d}} \pm 0.00$ & $\mathrm{P}<0.01$ \\
\hline P. a strain Exo25 & $16.33^{\mathrm{a}} \pm 0.88$ & $6.33^{\mathrm{b}} \pm 0.88$ & $6.00^{\mathrm{b}} \pm 1.16$ & $5.00^{b} \pm 0.58$ & $1.00^{\mathrm{C}} \pm 0.00$ & $\mathrm{P}<0.01$ \\
\hline P. $a$ strain R8-768 & $16.00^{\mathrm{a}} \pm 0.58$ & $6.67^{\mathrm{b}} \pm 0.88$ & $1.00^{c} \pm 0.00$ & $2.00^{C} \pm 0.58$ & $1.00^{\mathrm{C}} \pm 0.00$ & $\mathrm{P}<0.01$ \\
\hline P. $a$ strain YPAB1 & $22.67^{\mathrm{a}} \pm 1.45$ & $13.33^{\mathrm{b}} \pm 0.88$ & $4.00^{C} \pm 1.16$ & $2.00^{C} \pm 0.58$ & $1.00^{\mathrm{C}} \pm 0.00$ & $\mathrm{P}<0.01$ \\
\hline P. $a$ strain VITMS7 & $22.00^{\mathrm{a}} \pm 1.16$ & $15.67^{\mathrm{b}} \pm 0.88$ & $6.00^{\mathrm{c}} \pm 1.16$ & $2.00^{\mathrm{d}} \pm 0.58$ & $1.00^{\mathrm{d}} \pm 0.00$ & $\mathrm{P}<0.01$ \\
\hline P. $a$ strain AR442 & $12.00^{\mathrm{a}} \pm 1.16$ & $3.67^{\mathrm{b}} \pm 0.88$ & $3.33^{\mathrm{b}} \pm 0.67$ & $2.33^{C} \pm 0.67$ & $1.00^{\mathrm{C}} \pm 0.00$ & $\mathrm{P}<0.01$ \\
\hline P. $a$ strain AS23 & $16.33^{\mathrm{a}} \pm 0.88$ & $3.33^{b} \pm 0.88$ & $2.67^{\mathrm{b}} \pm 0.88$ & $2.00^{\mathrm{b}} \pm 0.58$ & $1.00^{\mathrm{b}} \pm 0.00$ & $\mathrm{P}<0.01$ \\
\hline P. $a$ strain DKH-3 & $23.00^{\mathrm{a}} \pm 1.16$ & $16.67^{\mathrm{b}} \pm 0.88$ & $3.00^{c} \pm 0.58$ & $4.00^{\mathrm{C}} \pm 1.00$ & $1.00^{\mathrm{d}} \pm 0.00$ & $\mathrm{P}<0.01$ \\
\hline P. $a$ strain $\mathrm{H} 25883$ & $22.0^{\mathrm{a}} \pm 1.16$ & $16.33^{\mathrm{b}} \pm 0.88$ & $14.00^{\mathrm{b}} \pm 0.58$ & $6.33^{\mathrm{C}} \pm 0.88$ & $1.00^{\mathrm{d}} \pm 0.00$ & $\mathrm{P}<0.01$ \\
\hline P. $a$ strain Y15 & $20.0^{\mathrm{a}} \pm 1.16$ & $12.67^{\mathrm{b}} \pm 1.45$ & $6.33^{c} \pm 0.88$ & $4.00^{\mathrm{d}} \pm 1.16$ & $1.00^{\mathrm{d}} \pm 0.00$ & $\mathrm{P}<0.01$ \\
\hline P. $a$ strain PA016 & $24.67^{\mathrm{a}} \pm 0.88$ & $6.67^{\mathrm{b}} \pm 0.88$ & $5.33^{\mathrm{b}} \pm 0.67$ & $1.67^{\mathrm{C}} \pm 0.33$ & $1.00^{\mathrm{C}} \pm 0.00$ & $\mathrm{P}<0.01$ \\
\hline P. $a$ strain R8- 768-1 & $25.00^{\mathrm{a}} \pm 1.16$ & $16.00^{\mathrm{b}} \pm 1.16$ & $12.00^{\mathrm{c}} \pm 1.16$ & $1.67^{d} \pm 0.33$ & $1.00^{\mathrm{d}} \pm 0.00$ & $\mathrm{P}<0.01$ \\
\hline P. $a$ strain KAR21 & $31.67^{\mathrm{a}} \pm 0.88$ & $15.00^{\mathrm{b}} \pm 1.16$ & $12.33^{\mathrm{b}} \pm 1.20$ & $1.33^{C} \pm 0.33$ & $1.00^{\mathrm{C}} \pm 0.00$ & $\mathrm{P}<0.01$ \\
\hline P. $a$ strain Iraq.PA -9 & $32.33^{\mathrm{a}} \pm 1.45$ & $22.00^{\mathrm{b}} \pm 1.16$ & $12.33^{\mathrm{C}} \pm 1.45$ & $6.67^{\mathrm{d}} \pm 0.67$ & $3.33^{\mathrm{d}} \pm 0.67$ & $\mathrm{P}<0.01$ \\
\hline
\end{tabular}

Similar letters indicate means that are not significantly different $(\mathrm{P}>0.05), \mathrm{P}<0.01$-Highly significantly different, $\mathrm{P}<0.001$ - Very highly significantly different. Values are mean \pm SEM. Reading of significance is row.

The antibacterial activity of M. oleifera aqueous methanol fraction of crude methanol leaf extracts on MDR Pseudomonas aeruginosa strains from surgical wound swab in Central Hospital Benin indicated that aqueous methanol fractions exhibited different levels of antibacterial activity when compared with the control as shown in Table 6. It was showed that there was a high significant difference in the mean zone of inhibition at the different concentrations. Highest mean zone of inhibition of $24.67 \pm 0.88$ millimeters was recorded for MDR Pseudomonas aeruginosa strains S2H16 and $9.67 \pm 0.33$ millimeters lowest acceptance zone of inhibition at $25 \mathrm{mg} / \mathrm{ml}$ was recorded for MDR P. aeruginosa strains D2 and P. aeruginosa strains H25883 respectively.

Table 6. Antibacterial activity of M. oleifera aqueous methanolic leaf extracts against different MDR Pseudomonas aeruginosa strains from CHB

\begin{tabular}{|c|c|c|c|c|c|c|}
\hline Isolates & $\begin{array}{c}100 \mathrm{mg} / \mathrm{ml} \\
\overline{\mathbf{X}} \pm \mathrm{SE}\end{array}$ & $\begin{array}{c}50 \mathrm{mg} / \mathrm{ml} \\
\bar{X} \pm S E\end{array}$ & $\begin{array}{c}25 \mathrm{mg} / \mathrm{ml} \\
\bar{X} \pm S E\end{array}$ & $\begin{array}{c}12.5 \mathrm{mg} / \mathrm{ml} \\
\bar{X} \pm \mathrm{SE}\end{array}$ & $\begin{array}{c}6.25 \mathrm{mg} / \mathrm{ml} \\
\bar{X} \pm \mathrm{SE}\end{array}$ & P-value \\
\hline P. $a$ strain PS2 & $19.67^{\mathrm{a}} \pm 0.33$ & $10.67^{\mathrm{b}} \pm 0.67$ & $4.33^{c} \pm 0.33$ & $1.00^{\mathrm{d}} \pm 0.00$ & $1.00^{\mathrm{d}} \pm 0.00$ & $\mathrm{P}<0.01$ \\
\hline P. $a$ strain NAPCC-1 & $20.33^{\mathrm{a}} \pm 0.33$ & $12.33^{\mathrm{b}} \pm 0.33$ & $4.67^{c} \pm 0.33$ & $1.00^{\mathrm{d}} \pm 0.00$ & $1.00^{\mathrm{d}} \pm 0.00$ & $\mathrm{P}<0.01$ \\
\hline P. $a$ strain DHS01 & $19.00^{\mathrm{a}} \pm 0.58$ & $10.33^{\mathrm{b}} \pm 0.33$ & $1.00^{\mathrm{C}} \pm 0.00$ & $1.00^{\mathrm{C}} \pm 0.00$ & $1.00^{\mathrm{C}} \pm 0.00$ & $\mathrm{P}<0.01$ \\
\hline P. $a$ strain AR442 & $19.67^{\mathrm{a}} \pm 0.33$ & $10.67^{\mathrm{b}} \pm 0.33$ & $6.00^{\mathrm{C}} \pm 1.00$ & $1.00^{\mathrm{d}} \pm 0.00$ & $1.00^{\mathrm{d}} \pm 0.00$ & $\mathrm{P}<0.01$ \\
\hline P. $a$ strain R7-520-1 & $23.33^{\mathrm{a}} \pm 1.20$ & $14.67^{\mathrm{b}} \pm 0.33$ & $7.67^{c} \pm 0.33$ & $1.00^{\mathrm{d}} \pm 0.00$ & $1.00^{\mathrm{d}} \pm 0.00$ & $\mathrm{P}<0.01$ \\
\hline P. $a$ strain H25883 & $23.00^{\mathrm{a}} \pm 1.53$ & $14.33^{\mathrm{b}} \pm 0.33$ & $9.67^{c} \pm 0.33$ & $1.00^{\mathrm{d}} \pm 0.00$ & $1.00^{\mathrm{d}} \pm 0.00$ & $\mathrm{P}<0.01$ \\
\hline P. $a$ strain PA-VAP-2 & $21.00^{\mathrm{a}} \pm 0.58$ & $15.33^{\mathrm{b}} \pm 0.33$ & $4.67^{\mathrm{C}} \pm 0.67$ & $1.00^{\mathrm{d}} \pm 0.00$ & $1.00^{\mathrm{d}} \pm 0.00$ & $\mathrm{P}<0.01$ \\
\hline P. $a$ strain R7-583 & $19.67^{\mathrm{a}} \pm 0.33$ & $9.67^{\mathrm{b}} \pm 0.33$ & $1.00^{\mathrm{C}} \pm 0.00$ & $1.00^{\mathrm{C}} \pm 0.00$ & $1.00^{\mathrm{C}} \pm 0.00$ & $\mathrm{P}<0.01$ \\
\hline P. $a$ strain PA006 & $19.67^{\mathrm{a}} \pm 0.33$ & $11.67^{\mathrm{b}} \pm 0.33$ & $4.67^{c} \pm 0.33$ & $1.00^{\mathrm{d}} \pm 0.00$ & $1.00^{\mathrm{d}} \pm 0.00$ & $\mathrm{P}<0.01$ \\
\hline P. $a$ strain $\mathrm{S} 2 \mathrm{H} 16$ & $24.67^{\mathrm{a}} \pm 0.88$ & $14.67^{\mathrm{b}} \pm 0.33$ & $9.67^{c} \pm 0.33$ & $4.67^{d} \pm 0.33$ & $1.00^{\mathrm{e}} \pm 0.00$ & $\mathrm{P}<0.01$ \\
\hline P. $a$ strain KAR21 & $23.67^{\mathrm{a}} \pm 0.88$ & $11.33^{\mathrm{b}} \pm 0.33$ & $7.33^{\mathrm{C}} \pm 0.33$ & $1.00^{\mathrm{d}} \pm 0.00$ & $1.00^{\mathrm{d}} \pm 0.00$ & $\mathrm{P}<0.01$ \\
\hline P. $a$ strain D2 & $15.00^{\mathrm{a}} \pm 0.58$ & $5.33^{\mathrm{b}} \pm 0.33$ & $1.00^{\mathrm{C}} \pm 0.00$ & $1.00^{\mathrm{C}} \pm 0.00$ & $1.00^{\mathrm{C}} \pm 0.00$ & $\mathrm{P}<0.01$ \\
\hline
\end{tabular}

Similar letters indicate means that are not significantly different $(\mathrm{P}>0.05), \mathrm{P}<0.01$-Highly significantly different, $\mathrm{P}<0.001$ - Very highly significantly different. Values are mean \pm SEM. Reading of significance is row. 
The antibacterial activity of residual aqueous methanol fraction of $M$. oleifera leaf crude methanol extracts on MDR Pseudomonas aeruginosa strains from UBTH indicated that different concentrations of the fraction exhibited antibacterial activity against tested isolates as shown in Table 7. Statistical analysis of data obtained revealed that there was a high significant difference in the mean zone of inhibition at the different concentrations. Highest mean zone of inhibition of $34.00 \pm 0.58$ millimeters and lowest acceptance zone of inhibition of $10.33 \pm 0.33$ millimeters at $12.5 \mathrm{mg} / \mathrm{ml}$ recorded for MDR P. aeruginosa strains KAR21.

Table 7. Antibacterial activity of $M$. oleifera aqueous methanol leaf extracts against different MDR Pseudomonas aeruginosa strains from UBTH

\begin{tabular}{|c|c|c|c|c|c|c|}
\hline Isolates & $\begin{array}{c}100 \mathrm{mg} / \mathrm{ml} \\
\bar{X} \pm S E\end{array}$ & $\begin{array}{c}50 \mathrm{mg} / \mathrm{ml} \\
\bar{X} \pm S E\end{array}$ & $\begin{array}{c}25 \mathrm{mg} / \mathrm{ml} \\
\bar{X} \pm S E\end{array}$ & $\begin{array}{c}12.5 \mathrm{mg} / \mathrm{ml} \\
\bar{X} \pm \mathrm{SE}\end{array}$ & $\begin{array}{c}6.25 \mathrm{mg} / \mathrm{ml} \\
\bar{X} \pm S E\end{array}$ & P-value \\
\hline P. $a$ strain SWD & $19.67^{\mathrm{a}} \pm 0.33$ & $11.33^{b} \pm 0.33$ & $9.67^{\mathrm{C}} \pm 0.33$ & $4.33^{\mathrm{d}} \pm 0.33$ & $1.00^{\mathrm{d}} \pm 0.00$ & $\mathrm{P}<0.01$ \\
\hline P. a strain Exo25 & $20.67^{\mathrm{a}} \pm 0.33$ & $10.33^{\mathrm{b}} \pm 0.33$ & $4.33^{c} \pm 0.33$ & $1.00^{\mathrm{d}} \pm 0.00$ & $1.00^{\mathrm{d}} \pm 0.00$ & $\mathrm{P}<0.01$ \\
\hline P. $a$ strain R8-768 & $18.33^{\mathrm{a}} \pm 0.33$ & $10.33^{\mathrm{b}} \pm 0.33$ & $5.67^{c} \pm 0.33$ & $1.00^{\mathrm{d}} \pm 0.00$ & $1.00^{\mathrm{d}} \pm 0.00$ & $\mathrm{P}<0.01$ \\
\hline P. $a$ strain YPAB1 & $20.33^{\mathrm{a}} \pm 0.33$ & $9.67^{\mathrm{b}} \pm 0.00$ & $1.00^{\mathrm{c}} \pm 0.00$ & $1.00^{\mathrm{c}} \pm 0.00$ & $1.00^{\mathrm{c}} \pm 0.00$ & $\mathrm{P}<0.01$ \\
\hline P. $a$ strain VITMS7 & $15.00^{\mathrm{a}} \pm 1.73$ & $10.67^{\mathrm{b}} \pm 0.33$ & $1.00^{\mathrm{C}} \pm 0.00$ & $1.00^{\mathrm{c}} \pm 0.00$ & $1.00^{\mathrm{C}} \pm 0.00$ & $\mathrm{P}<0.01$ \\
\hline P. $a$ strain AR442 & $19.67^{\mathrm{a}} \pm 0.33$ & $12.33^{\mathrm{b}} \pm 0.33$ & $4.33^{\mathrm{C}} \pm 0.33$ & $1.00^{\mathrm{d}} \pm 0.00$ & $1.00^{\mathrm{d}} \pm 0.00$ & $\mathrm{P}<0.01$ \\
\hline P. $a$ strain AS23 & $20.00^{\mathrm{a}} \pm 0.58$ & $15.67^{b} \pm 0.67$ & $10.33^{\mathrm{c}} \pm 0.33$ & $1.00^{\mathrm{d}} \pm 0.00$ & $1.00^{\mathrm{d}} \pm 0.00$ & $\mathrm{P}<0.01$ \\
\hline P. $a$ strain DKH-3 & $20.33^{\mathrm{a}} \pm 0.33$ & $11.00^{\mathrm{b}} \pm 0.58$ & $10.67^{\mathrm{b}} \pm 0.67$ & $1.00^{\mathrm{c}} \pm 0.00$ & $1.00^{\mathrm{c}} \pm 0.00$ & $\mathrm{P}<0.05$ \\
\hline P. $a$ strain $\mathrm{H} 25883$ & $17.67^{\mathrm{a}} \pm 0.88$ & $11.33^{\mathrm{b}} \pm 0.88$ & $4.33^{c} \pm 0.33$ & $1.00^{\mathrm{d}} \pm 0.00$ & $1.00^{\mathrm{d}} \pm 0.00$ & $\mathrm{P}<0.01$ \\
\hline P. $a$ strain Y15 & $24.67^{\mathrm{a}} \pm 0.33$ & $12.67^{\mathrm{b}} \pm 0.67$ & $9.33^{c} \pm 0.33$ & $4.67^{d} \pm 0.33$ & $1.00^{\mathrm{e}} \pm 0.00$ & $\mathrm{P}<0.01$ \\
\hline P. $a$ strain PA016 & $15.33^{\mathrm{a}} \pm 0.33$ & $8.67^{\mathrm{b}} \pm 0.67$ & $1.00^{\mathrm{c}} \pm 0.00$ & $1.00^{\mathrm{c}} \pm 0.00$ & $1.00^{\mathrm{c}} \pm 0.00$ & $\mathrm{P}<0.01$ \\
\hline P. $a$ strain R8- 768-1 & $15.33^{\mathrm{a}} \pm 0.33$ & $11.00^{\mathrm{b}} \pm 0.58$ & $1.00^{c} \pm 0.00$ & $1.00^{\mathrm{C}} \pm 0.00$ & $1.00^{\mathrm{C}} \pm 0.00$ & $\mathrm{P}<0.01$ \\
\hline P. $a$ strain KAR21 & $34.00^{\mathrm{a}} \pm 0.58$ & $24.67^{\mathrm{b}} \pm 0.33$ & $18.33^{\mathrm{C}} \pm 0.33$ & $10.33^{d} \pm 0.33$ & $7.67^{\mathrm{e}} \pm 0.33$ & $\mathrm{P}<0.01$ \\
\hline P. $a$ strain Iraq.PA -9 & $15.33^{\mathrm{a}} \pm 0.33$ & $1.00^{\mathrm{b}} \pm 0.00$ & $1.00^{\mathrm{b}} \pm 0.00$ & $1.00^{\mathrm{b}} \pm 0.00$ & $1.00^{\mathrm{b}} \pm 0.00$ & $\mathrm{P}<0.01$ \\
\hline
\end{tabular}

Similar letters indicate means that are not significantly different $(\mathrm{P}>0.05), \mathrm{P}<0.01$-Highly significantly different, $\mathrm{P}<0.001$ - Very highly significantly different. Values are mean \pm SEM. Reading of significance is row.

The antibacterial property of n-hexane fraction of crude methanol M. oleifera leaf extracts on MDR Pseudomonas aeruginosa strains indicated that n-hexane fractions from Central Hospital Benin showed different levels of antibacterial activity when compared with the control as shown in Table 8. It was showed that there was a high significant difference in the mean zone of inhibition at the different concentrations of the extract. The highest mean zone of inhibition of $40.33 \pm 0.33$ and $40.00 \pm 0.58$ millimeters was recorded for MDR P. aeruginosa strains NAPCC-1 and MDR P. aeruginosa strains R7-520-1 respectively. Meanwhile, lowest acceptable zone of inhibition of $9.33 \pm 0.67$ millimeters at $6.25 \mathrm{mg} / \mathrm{ml}$ was recorded for MDR P. aeruginosa strain PA-VAP-2.

Table 8. Antibacterial activity of M. oleifera n-Hexane leaf extracts against different MDR Pseudomonas aeruginosa strains from CHB

\begin{tabular}{|c|c|c|c|c|c|c|}
\hline Isolates & $\begin{array}{c}100 \mathrm{mg} / \mathrm{ml} \\
\bar{X} \pm \mathrm{SE}\end{array}$ & $\begin{array}{c}50 \mathrm{mg} / \mathrm{ml} \\
\bar{X} \pm S E\end{array}$ & $\begin{array}{c}25 \mathrm{mg} / \mathrm{ml} \\
\bar{X} \pm S E\end{array}$ & $\begin{array}{c}\text { 12.5mg/ml } \\
\bar{X} \pm S E\end{array}$ & $\begin{array}{c}6.25 \mathrm{mg} / \mathrm{ml} \\
\overline{\mathrm{X}} \pm \mathrm{SE}\end{array}$ & P-value \\
\hline P. $a$ strain PS2 & $36.00^{\mathrm{a}} \pm 0.58$ & $24.67^{\mathrm{b}} \pm 0.33$ & $20.67^{c} \pm 0.33$ & $15.33^{\mathrm{d}} \pm 0.00$ & $10.33^{\mathrm{e}} \pm 0.33$ & $\mathrm{P}<0.01$ \\
\hline P. $a$ strain NAPCC-1 & $40.33^{\mathrm{a}} \pm 0.33$ & $21.67^{\mathrm{b}} \pm 0.33$ & $20.33^{\mathrm{b}} \pm 0.33$ & $13.00^{\mathrm{c}} \pm 1.00$ & $1.00^{\mathrm{d}} \pm 0.00$ & $\mathrm{P}<0.01$ \\
\hline P. $a$ strain DHS01 & $30.33^{\mathrm{a}} \pm 0.33$ & $20.33^{b} \pm 0.33$ & $16.00^{c} \pm 0.58$ & $10.67^{\mathrm{d}} \pm 0.67$ & $8.67^{\mathrm{e}} \pm 0.67$ & $\mathrm{P}<0.01$ \\
\hline P. $a$ strain AR442 & $25.00^{\mathrm{a}} \pm 0.58$ & $21.00^{\mathrm{b}} \pm 0.58$ & $15.33^{\mathrm{c}} \pm 0.33$ & $13.00^{\mathrm{d}} \pm 0.58$ & $10.67^{\mathrm{e}} \pm 0.67$ & $\mathrm{P}<0.01$ \\
\hline P. $a$ strain R7-520-1 & $40.00^{\mathrm{a}} \pm 0.58$ & $20.33^{\mathrm{b}} \pm 0.33$ & $10.33^{\mathrm{c}} \pm 0.33$ & $4.67^{\mathrm{d}} \pm 0.67$ & $2.00^{\mathrm{e}} \pm 0.00$ & $\mathrm{P}<0.01$ \\
\hline P. $a$ strain $\mathrm{H} 25883$ & $31.00^{\mathrm{a}} \pm 0.58$ & $20.33^{\mathrm{b}} \pm 0.33$ & $21.00^{\mathrm{b}} \pm 0.58$ & $11.33^{\mathrm{C}} \pm 0.67$ & $1.67^{\mathrm{d}} \pm 0.33$ & $\mathrm{P}<0.01$ \\
\hline P. $a$ strain PA-VAP-2 & $22.33^{\mathrm{a}} \pm 0.33$ & $14.67^{\mathrm{b}} \pm 0.33$ & $13.67^{\mathrm{b}} \pm 0.88$ & $12.67^{\mathrm{b}} \pm 0.67$ & $9.33^{\mathrm{C}} \pm 0.67$ & $\mathrm{P}<0.01$ \\
\hline P. $a$ strain R7-583 & $30.33^{\mathrm{a}} \pm 0.33$ & $25.33^{\mathrm{b}} \pm 0.33$ & $20.33^{c} \pm 0.33$ & $17.00^{\mathrm{d}} \pm 0.58$ & $11.00^{\mathrm{e}} \pm 0.58$ & $\mathrm{P}<0.01$ \\
\hline P. $a$ strain PA006 & $30.00^{\mathrm{a}} \pm 0.58$ & $21.00^{\mathrm{b}} \pm 0.58$ & $15.33^{\mathrm{C}} \pm 0.33$ & $9.00^{\mathrm{d}} \pm 0.58$ & $5.67^{\mathrm{e}} \pm 0.67$ & $\mathrm{P}<0.01$ \\
\hline P. $a$ strain $\mathrm{S} 2 \mathrm{H} 16$ & $29.00^{\mathrm{a}} \pm 0.58$ & $18.33^{\mathrm{b}} \pm 0.33$ & $10.33^{\mathrm{C}} \pm 0.33$ & $5.33^{d} \pm 0.33$ & $2.00^{\mathrm{e}} \pm 0.00$ & $\mathrm{P}<0.01$ \\
\hline P. $a$ strain KAR21 & $20.67^{\mathrm{a}} \pm 0.33$ & $15.33^{\mathrm{b}} \pm 0.33$ & $10.33^{\mathrm{C}} \pm 0.33$ & $5.00^{\mathrm{d}} \pm 0.58$ & $2.00^{\mathrm{e}} \pm 0.00$ & $\mathrm{P}<0.01$ \\
\hline P. $a$ strain D2 & $39.67^{\mathrm{a}} \pm 0.88$ & $35.33^{\mathrm{b}} \pm 0.33$ & $21.00^{c} \pm 0.58$ & $11.33^{\mathrm{d}} \pm 0.67$ & $11.00^{\mathrm{d}} \pm 0.58$ & $\mathrm{P}<0.01$ \\
\hline
\end{tabular}

Similar letters indicate means that are not significantly different $(\mathrm{P}>0.05), \mathrm{P}<0.01$-Highly significantly different, $\mathrm{P}<0.001$ - Very highly significantly different. Values are mean \pm SEM. Reading of significance is row.

The antibacterial effect of n-hexane fraction of crude methanol M. oleifera leaf extracts on MDR Pseudomonas 
aeruginosa strains from UBTH indicated that n-hexane fractions revealed that different concentrations of antibacterial activity as shown in Table 9. High significant difference in the mean zone of inhibition at the different concentrations of the extract was observed. The highest mean zone of inhibition of $31.00 \pm 0.58$ millimeters was recorded for MDR P. aeruginosa strains Y15 and lowest acceptable zone of inhibition of $10.33 \pm 1.16$ millimeters at $12.5 \mathrm{mg} / \mathrm{ml}$ was recorded for MDR P. aeruginosa strains R8-768-1.

Table 9. Antibacterial activity of M. oleifera n-hexane leaf extracts against different MDR Pseudomonas aeruginosa strains from UBTH

\begin{tabular}{|c|c|c|c|c|c|c|}
\hline Isolates & $\begin{array}{c}100 \mathrm{mg} / \mathrm{ml} \\
\bar{X} \pm S E\end{array}$ & $\begin{array}{c}50 \mathrm{mg} / \mathrm{ml} \\
\bar{X} \pm \mathrm{SE}\end{array}$ & $\begin{array}{c}25 \mathrm{mg} / \mathrm{ml} \\
\bar{X} \pm \mathrm{SE}\end{array}$ & $\begin{array}{c}12.5 \mathrm{mg} / \mathrm{ml} \\
\bar{X} \pm \mathrm{SE}\end{array}$ & $\begin{array}{c}6.25 \mathrm{mg} / \mathrm{ml} \\
\bar{X} \pm \mathrm{SE}\end{array}$ & P-value \\
\hline P. $a$ strain SWD & $30.67^{\mathrm{a}} \pm 0.67$ & $21.00^{\mathrm{b}} \pm 0.58$ & $11.33^{\mathrm{C}} \pm 0.67$ & $2.67^{\mathrm{d}} \pm 0.67$ & $1.00^{\mathrm{d}} \pm 0.00$ & $\mathrm{P}<0.01$ \\
\hline P. $a$ strain Exo25 & $25.33^{\mathrm{a}} \pm 0.33$ & $20.67^{\mathrm{b}} \pm 0.67$ & $12.67^{c} \pm 0.67$ & $9.00^{\mathrm{d}} \pm 0.58$ & $4.67^{\mathrm{e}} \pm 0.67$ & $\mathrm{P}<0.01$ \\
\hline P. $a$ strain R8-768 & $18.67^{\mathrm{a}} \pm 0.67$ & $10.67^{\mathrm{b}} \pm 0.67$ & $8.00^{C} \pm 1.16$ & $2.67^{\mathrm{d}} \pm 0.67$ & $1.67^{\mathrm{d}} \pm 0.33$ & $\mathrm{P}<0.05$ \\
\hline P. $a$ strain YPAB1 & $29.33^{\mathrm{a}} \pm 0.67$ & $18.67^{\mathrm{b}} \pm 0.67$ & $11.33^{c} \pm 0.67$ & $3.33^{\mathrm{d}} \pm 0.67$ & $2.00^{\mathrm{d}} \pm 0.00$ & $\mathrm{P}<0.01$ \\
\hline P. $a$ strain VITMS7 & $15.67^{\mathrm{a}} \pm 0.33$ & $10.67^{\mathrm{b}} \pm 0.67$ & $8.00^{c} \pm 1.16$ & $4.67^{\mathrm{d}} \pm 0.67$ & $1.00^{\mathrm{e}} \pm 0.00$ & $\mathrm{P}<0.01$ \\
\hline P. $a$ strain AR442 & $19.67^{\mathrm{a}} \pm 0.88$ & $17.33^{b} \pm 0.67$ & $11.00^{C} \pm 0.58$ & $3.00^{\mathrm{d}} \pm 0.58$ & $1.00^{\mathrm{e}} \pm 0.00$ & $\mathrm{P}<0.01$ \\
\hline P. $a$ strain AS23 & $19.33^{\mathrm{a}} \pm 0.67$ & $15.00^{\mathrm{b}} \pm 0.58$ & $10.67^{\mathrm{C}} \pm 0.67$ & $2.00^{\mathrm{d}} \pm 0.00$ & $2.00^{\mathrm{d}} \pm 0.00$ & $\mathrm{P}<0.01$ \\
\hline P. $a$ strain DKH-3 & $19.00^{\mathrm{a}} \pm 0.58$ & $10.67^{\mathrm{b}} \pm 0.67$ & $5.33^{\mathrm{C}} \pm 0.33$ & $2.00^{\mathrm{d}} \pm 0.00$ & $2.00^{\mathrm{d}} \pm 0.00$ & $\mathrm{P}<0.01$ \\
\hline P. $a$ strain H25883 & $25.33^{\mathrm{a}} \pm 0.33$ & $21.00^{\mathrm{b}} \pm 0.58$ & $4.67^{c} \pm 0.67$ & $2.00^{\mathrm{d}} \pm 0.00$ & $2.00^{\mathrm{d}} \pm 0.00$ & $\mathrm{P}<0.01$ \\
\hline P. a strain Y15 & $31.00^{\mathrm{a}} \pm 0.58$ & $22.33^{\mathrm{b}} \pm 0.33$ & $16.00^{c} \pm 0.58$ & $1.00^{\mathrm{d}} \pm 0.00$ & $1.00^{\mathrm{d}} \pm 0.00$ & $\mathrm{P}<0.01$ \\
\hline P. a strain PA016 & $16.33^{\mathrm{a}} \pm 0.88$ & $12.33^{\mathrm{b}} \pm 1.45$ & $9.33^{c} \pm 0.67$ & $2.00^{\mathrm{d}} \pm 0.00$ & $2.00^{\mathrm{d}} \pm 0.00$ & $\mathrm{P}<0.05$ \\
\hline P. $a$ strain R8- 768-1 & $19.00^{\mathrm{a}} \pm 0.58$ & $21.00^{\mathrm{a}} \pm 0.58$ & $15.67^{\mathrm{b}} \pm 0.33$ & $10.00^{C} \pm 1.16$ & $8.00^{\mathrm{C}} \pm 2.00$ & $\mathrm{P}<0.05$ \\
\hline P. $a$ strain KAR21 & $21.67^{\mathrm{a}} \pm 0.88$ & $19.00^{\mathrm{a}} \pm 0.58$ & $13.00^{\mathrm{b}} \pm 0.58$ & $11.33^{b} \pm 0.67$ & $6.67^{\mathrm{c}} \pm 1.76$ & $\mathrm{P}<0.05$ \\
\hline P. $a$ strain Iraq.PA -9 & $21.00^{\mathrm{a}} \pm 0.58$ & $13.00^{\mathrm{b}} \pm 0.58$ & $1.00^{\mathrm{C}} \pm 0.00$ & $1.00^{\mathrm{C}} \pm 0.00$ & $1.00^{\mathrm{C}} \pm 0.00$ & $\mathrm{P}<0.01$ \\
\hline
\end{tabular}

Similar letters indicate means that are not significantly different $(\mathrm{P}>0.05), \mathrm{P}<0.01$-Highly significantly different, $\mathrm{P}<0.001$ - Very highly significantly different. Values are mean \pm SEM. Reading of significance is row.

\section{Discussion}

Notwithstanding the several conventional medications in use for the treatment and management of various pathophysiological conditions, observable limitations ranging from relatively high cost to somewhat unavailability has been documented $[3,35]$. Owing to this, it has become necessary for a switch to a readily available and cheaper alternative in the form of phyto/herbal medicine. Accordingly, the World Health Organization recommends the use of medicinal plants as a therapeutic source for the management of various pathophysiological conditions, and also encouraged the expansion of the frontiers of scientific evaluation on properties of varied plant species [3]. Hence, the present study examined the action of fractionated Moringa oleifera lam leaf extracts on multidrug resistant Pseudomonas aeruginosa strains. The result showed that two hundred and eighty-four post-operative surgical wound swabs specimens from patients (one hundred and forty-two from each location) were analyzed. Ninety-nine (35\%) of patients studied had wound infection. Although this is lower than 39.9\% previously reported [36] but higher than 9.6\% reported by [37]. However, World Health Organization gave a prevalence of 5\%-34\% of surgical site infection and this is in agreement with the result of this study. The distribution of etiologic agents of surgical wound infections showed that $P$. aeruginosa (62.6\%) was found to be more predominant. This is in conformity with the study of Agbonlahor et al. (2018) who also found that $P$. aeruginosa were more prevalent in surgical wound infections [38]. Thirty-four (54.8\%) strains were found to be multidrug resistant Pseudomonas aeruginosa isolates. The broad spread of antibiotic resistant genes among bacteria as well as P. aeruginosa strains is a rising worry in the cure of post-surgical wound infections. In this study, the antibiotic sensitivity testing revealed that most of our isolates showed resistance $(>50.0 \%)$ to commonly used antibiotics. [39], reported high resistance of bacterial isolates from clinical samples to first, second and third generation antibiotics. [40] reported that bacterial isolated from surgical wound infections are mostly resistant to Ceftazidime and Augmentin. This is most likely to be due to the presence of enzymes such as Cephalosporinase and Penicillinase which can prevent the activity of Beta-lactam ring of the antibiotics [38]. Current problems linked with the use of antibiotics, increased prevalence of multiple drug resistant (MDR) strains of a number of pathogenic bacteria has revitalized the interest in plants with antimicrobial properties [41]. The antimicrobial properties of Moringa oleifera have been ascribed to the diverse parts of the plant, such as the leaves, seeds, pods and stems [42] which are recognized for their antibacterial action and are counted as rich basis of antimicrobial agents [43]. In this study, phytochemical screening (qualitative analysis) was 
used to reveal the secondary metabolites of the Moringa oleifera leaf extract. M. oleifera revealed the presence of flavonoids, phenol, saponins, steroids, tannin and terpenoids (Table 2). Flavonoids, phenol and saponins were present in methanol and aqueous methanol extracts. Tannins were present in only methanol extract and absent in aqueous methanol and n-Hexane fractions. Steriods and terpenoids were present in methanol, aqueous methanol and n-Hexane fractions while flavonoids, phenol and saponins were absent in n-Hexane fractions. In the study of [44], phytochemical analysis of Moringa oleifera leaf extracts shows the presence of flavonoids, saponins, sterols and tannins in both aqueous and ethanolic extracts. Occurrence of flavonoids, saponins, sterols and tannins in Guava (Psidium guajava L.) aqueous, ethanol and chloroform leaf extracts was reported by [45]. [46] reported the presence of flavonoids, saponins, steroids, terpenoids and tannins in Moringa oleifera leaf extract. These findings also correspond with the documented report by [47]. Nevertheless, [48] reported absence of steroids, terpenoids and cardiac glycoside while [49] reported absence of terpenoids and cardiac glycoside in Moringa oleifera leaf extract. It has been documented that various solvents used for extraction have different extraction capabilities and spectrum of solubility for the phytochemical constituents [50]. Quantitative analysis of secondary metabolites can help to disclose the chemical composition of the plant extract and to identify which phytochemical dominate over the other. This analysis can as well be used to find bioactive constituents for development of products that may enclose medicinal values [51]. The quantitative analysis results of the secondary metabolites in Moringa oleifera revealed the amount of flavonoids in crude methanol leaf extract was $(202.845 \pm 53.88 \mathrm{mg} / \mathrm{g})$, amount of phenol was (46.027 \pm $2.871 \mathrm{mg} / \mathrm{g})$, amount of saponins was $(105.9 \pm 7140 \mathrm{mg} / \mathrm{g})$, amount of sterols was $(2.9 \pm 2.950 \mathrm{mg} / \mathrm{ml})$, amount of tannins was $(69.473 \pm 4.868 \mathrm{mg} / \mathrm{g})$ and amount of terpenoids was $(33.83 \pm 29.796 \mathrm{mg} / \mathrm{ml})$ using different standards based on the phytochemical. In another study, quantitative analysis $M$. oleifera extract showed various amount of phytochemical constituents including terpenoids (4.84 \pm 0.05$)$, tannins (9.36 \pm 0.04$)$, flavonoid (3.56 \pm 0.03$)$ and saponins (1.46 \pm 0.03$)$ all in $\mathrm{g} / 100 \mathrm{~g}$ which were lower when compared to the result in our study but steroids (3.21 \pm 0.00 ) was higher when compared with our result [46]. In Emblica officinalis pod extract, the quantity of flavonoids obtained was (0.04\%), amount of saponins was (0.55\%), and quantity of tannins was (1.10\%), [52]. Fruit extract of Tribulus terrestris also revealed that the quantity of flavonoids was (1.10\%), amount of saponins was (0.85\%), and amount of tannins was (1.25\%) [53]. In some plant parts, the amount of these phytoconstituents is comparatively higher than others as reported by [54].

The antibacterial activity of methanol, aqueous methanol and n-Hexane extracts of dried Moringa oleifera leaf was determined using different strains of Pseudomonas aeruginosa isolated from post-surgical wound patients in two government owned hospitals in Benin City, Nigeria. All three M. oleifera leaf extracts tested had different inhibitory effect on the various Pseudomonas aeruginosa strains at the different concentrations. There was significant antimicrobial activity demonstrated by the n-Hexane fractions for P. aeruginosa strains NAPCC- 1 isolated from surgical wound patients in Central Hospital Benin (CHB) being the most susceptible organism followed by aqueous methanol and methanol extract for P. aeruginosa strains S2H16 and P. aeruginosa strains R7-520-1 respectively all at a concentration of $100 \mathrm{mg} / \mathrm{ml}$. The least considerable zone of inhibition (10.33 \pm 0.33$)$ was observed in n-Hexane fractions for P. aeruginosa strains P2S at a concentration of $6.25 \mathrm{mg} / \mathrm{ml}$ followed by aqueous methanol and methanol extract at a concentration of $25 \mathrm{mg} / \mathrm{ml}$. On the other hand, aqueous methanol extract was observed to be more susceptible for $P$. aeruginosa strains KAR21 followed by methanol extract best for $P$. aeruginosa strains Iraq. PA-9 then n-Hexane for P. aeruginosa strains Y15 isolated from University of Benin Teaching Hospital (UBTH) all at a concentration of $100 \mathrm{mg} / \mathrm{ml}$. Moreso, the least active concentration was observed in aqueous methanol and $\mathrm{n}$-Hexane fractions $(10.33 \pm 0.33,10.00 \pm 1.16$ respectively) at $12.5 \mathrm{mg} / \mathrm{ml}$ followed by methanol at $25 \mathrm{mg} / \mathrm{ml}$ concentration. Our findings conform to other reports on the antibacterial activity of Moringa oleifera extracts [55, 56, 57].

[48] employed methanol and aqueous extracts of the Moringa seeds and reported considerable inhibitory action against bacterial isolated from wound infections, including $E$. coli. They as well affirmed the broad spectrum activity of M. oleifera extracts. [58] had also reported that methanolic and purified dichloromethane M. oleifera extracts had antimicrobial action against both Gram positive and negative organisms. In another study by [59] reported that both methanol and n-hexane extracts of Moringa oleifera displayed antibacterial activity against $S$. typhi. Findings from this work reveal that Moringa leaf extract had both bactericidal and bacteriostatic activity on the different $P$. aeruginosa strains tested. This is an indication that the leaf extracts may possibly be used in the treatment of post-surgical wound infection caused by multiple drug resistant $P$. aeruginosa strains. Antimicrobial phytochemicals especially tannins work by binding with the cell walls and inactivate the enzymes [60]. M. oleifera leaf rich in tannins have prove why it is used in treatment of infection and healing of wounds [61]. It has been reported that the presence of terpenoids and saponins may cause hemolysis [62], flavonoids have been reported to inhibit nucleic 
acid synthesis, alteration in cytoplasmic membrane function, energy metabolism inhibition, decrease in cell attachment and varying of the membrane permeability [63]. The worldwide emergence of multiple drug resistant $P$. aeruginosa strains is increasing, limiting the efficacy of recent drugs and treatment failure of infections. Novel move towards the prevention of antibiotic resistance of pathogenic organisms by employing new compounds that are not based on existing synthetic antimicrobial agents is the way to go in tackling this menace. Based on the outcome of this study, it could be suggested that extracts of this plant should be further analyzed to isolate the specific antibacterial compounds. Clinical trials should be encouraged to investigate the pharmaceutical potential of this medicinal plant in the treatment of bacterial infections.

\section{Conclusion and Recommendation}

Although all extracts showed varying antibacterial effect, n-Hexane M. oleifera leaf extract showed highest degrees of antimicrobial activity on the microorganisms tested. n-Hexane extract exhibited a higher degree of antimicrobial activity when compared with other extracts. The activity of $M$. oleifera indicated a powerful source of new antimicrobial substitute. However, further work is needed to isolate the secondary metabolites from the extract in order to test for specific antimicrobial activity. There is also the need for more work to be carried out to establish the conflicting findings from various laboratories on the efficacy of the M. oleifera extracts. This in vitro study demonstrated that folk medicine can be as effective as modem medicine to combat pathogenic microorganisms. According to World Health Organization, microbial resistance to routine antibiotics is on the rise and medicinal plants offer a good source of alternative. Moringa oleifera represents an economic and safe option to treat infections in addition to several other uses.

\section{Conflict of Interests}

The authors hereby declare that there is no conflict of interests over this article as we did not received support from any individual or organization.

\section{References}

[1] Ajibade, L., Fatoba, P., Raheem, U., and Odunuga, B. (2005). Ethnomedicine and primary healthcare in Ilorin, Nigeria. Indian Journal of Traditional Knowledge, 4(2): 150-158.

[2] Nascimento, G. G. F., Locatelli, J., Freitas, P. C., and Silva, G. L. (2000). Antibacterial activity of plant extracts and phytochemical on antibacterial-resistant bacteria. Brazilian Journal of Microbiology, 31(4): 247-256.

[3] Nwawuba, S. U., Monago, C. C., and Mejulu, K. C. (2019). Ameliorative effect of aqueous seed extract of delonix regia on hyperglycemia, liver function and lipid profile levels in Streptozotocin induced Diabetic Male wistar rats. Pharmacy and Pharmacology International Journal, 7(3): 126-131.

[4] Igbinosa, O. O., Igbinosa, E. O., and Aiyegoro, O. A. (2009). Antimicrobial activity and phytochemical screening of stem bark extracts from Jatropha curcas (Linn). Afr. J. Pharm. Pharmacol., 3(2): 058-062.

[5] Mahomed, I. M. and Ojewole, J. A. O. (2006). Anticonvulsant activity of Harpagophytum procumbens DC (Pedaliaceae) secondary root aqueous extract in mice. Brain Research Bulletin, 69: 57-62.

[6] Nwozo, S. O., Nyam, A. N., Nwawuba, S. U., and Olukotun, O. I. (2019). Hypoglycemic and Antioxidant Capacity of Curcuma Longa and Viscum Album in Alloxan Induced Diabetic Male Wistar Rats. International Journal of Diabetes and Endocrinology, 4(1): 26-34.

[7] Farooq, A., Sajid, L., Muhammad, A., and Anwarul Hassan, G. (2007). Moringa oleifera: a food plant with multiple medicinal uses. Phytotherapy Research, 21: 17-25.

[8] Bukar, A., Uba, A., and Oyeyi, T. I. (2010). Antimicrobial profile of moringa oleifera lam. Extracts against some food-borne microorganisms. Bayero Journal of Pure and Applied Sciences, 3(1): 43-48.

[9] Mehta, L. K., Balaraman, R., Amin, A. H., Baffa, P. A., and Gulati, O. D. (2003). Effects of fruits of M. oleifera on the lipid profile of normal and hypercholesterolaemic rabbits. Journal of Ethnopharmacology, 86: 191-195.

[10] Nickon, F., Saud, Z. A., Rehman, M. H., and Haque, M. E. (2003). In vitro antimicrobial activity of the compound isolated from chloroform extract of M. oleifera Lam. Pakistan Journal of Biological Sciences, 22: 1888-1890.

[11] Kawo, A. H. (2007). Water purification potentials and in-vivo toxicity evaluation of the aqueous and petroleum ether extracts of Calotropis procera (Ait.F) Ait.F. latex and Moringa oleifera Lam seed powder. PhD thesis, Microbiology Unit, Department of Biological Sciences, Bayero University, Kano. P. 184.

[12] Broin, M., Santaella, C., Cuine, S., Kokou, K., Peltier, G., and Joet, T. (2002). Flocculent activity of a recombinant protein from Moringa oleifera Lam. Seeds. Appl. Microbiol. Biotechnol., 60: 114-119.

[13] Sharma, P., Kumari, P., Srivastava, M. M., and Srivastava, S. (2006). Removal of cadmium from aqueous system by shelled M. 
oleifera Lam. seed powder. Bioresource Technology, 97: 299-305.

[14] Strateva, T. and Yordanov, D. (2009). Pseudomonas aeruginosa; A phenomenon of bacterial resistance. J. Med. Microbiol., 58(9): 1133-1148.

[15] Church, D., Elsayed, S., Reid, O., Winston, B., and Lindsay, R. (2009). Burn wound infections. Clin. Microbiol. Rev., 19(2): 403-434.

[16] Fair, R. J. and Tor, Y. (2014). Antibiotics and bacterial resistance in the 21st century. Perspect. Medicin. Chem., 6: 25-64.

[17] Breidenstein, E. B., de la Fuente-NuÂ ñez, C., and Hancock, R. E. (2011). Pseudomonas aeruginosa: all roads lead to resistance. Trends Microbiol., 19(8): 419-426.

[18] Shittu, H. O., Aghogban, O. N., Akaluzia, H. C., and Chibuogwu, M. O. (2017). A comparison of callus production from Moringa oleifera Lam. leaf, cotyledon and stem explants using 2,4- Dichlorophenoxyacetic acid and kinetin for media supplementation. SAU Sci-Tech J., 1(2): 1-6.

[19] Shobayo, B. I., Ojo, D. A., Olaboopo, A. O., Agboola, D. A., Omemu, A. M., and Akingbade, O. A. (2014). Antibacterial activity of Moringa oleifera on Multi-drug resistant isolates from wound infections in Abeokuta, South-West Nigeria. N Y Sci. J., 7(12): $1-7$.

[20] Akueshi, C. O., Kadiri, C. O., Akueshi, E. U., Agina, S. E., and Ngurukwem, B. (2002). Antimicrobial potentials of Hyptis sauvedens Poit (Lamiaccae). Nigeria. J Bot., 15: 37-41.

[21] Jamil, M., Haq, I. U., Mirza, B., and Qayyum, M. (2012). Isolation of antibacterial compounds from Quercus dilatata L. through bioassay guided fractionation. Annals of Clinical Microbiology and Antimicrobials, 11: 11.

[22] Devmurari, V. P. (2010). Phytochemical screening study and antibacterial evaluation of Symplocos racemosa Roxb. Archives of Applied Science Research, 2(1): 354-359.

[23] Sabri, F. Z., Belarbi, S. S., and Alsayadi, M. M. S. (2012). Phytochemical screening and identification of some compounds from Mallow. J. Nat. Plant Resour., 2(4): 512-516.

[24] Parmar, P., Bhatt, S. D., and Jain, A. (2012). Phytochemical studies of the secondary metabolites of Ziziphusm auritiana. International Journal of current Pharmaceutical Research, 4(3): 153-155.

[25] Ajay, A., Ude, A. N., and Balogun, O. J. (2017). Qualitative and quantitative phytochemical analysis of Moringa oleifera and Vernonia amygdalina. FULafia Journal of Science \& Technology, 3(2): 51-57.

[26] Solihah, M. A., Rosli, W. I., and Nurhanan, A. R. (2012). Phytochemical screening and total phenolic content of Malaysian Zea mays. Int. food Res. J., 19(4): 1533-1538.

[27] Ejikeme, C. M., Ezeonu, C. S., and Eboatu, A. N. (2014). Determination of physical and phytochemical constituents of some tropical timbers indigenous to Niger Delta Area of Nigeria. European Scientific Journal, 10(18): 247-270.

[28] Thilagavathi, T., Arvindganth, R., Vidhya, D., Dhivya, R. (2015). International Research Journal of Pharmacy, 6(4): $246-248$.

[29] Snehlata, K., Rimjhim, S., and Baidyanath, K. (2018). Evaluation of phytochemicals in polar and Non-polar solvent extracts of leaves of Aegle marmelos (L.). Journal of Biotechnology and Biochemistry, 4(5): 31-38.

[30] Kim, D. O., Being, S. W., and Lee, C. Y. (2003). Antioxidant capacity of phenolic phytochemicals from various cultivars of plums. Food Chemistry, 81: 321-326.

[31] Ebrahimzadeh, M. A., Pourmorad, F., and Bekhradnia, A. R. (2008). "Iron chelating activity, phenol and flavonoid content of some medicinal plants from Iran”. African Journal of Biotechnology, 7(18): 3188-3192.

[32] Ezeabara, C. A., Okeke, C. U., Aziagba, B. O., Ilodibia, C. V., and Emeka, V. N. (2014). Determination of saponin content of various parts of six citrus species. International Research Journal of Pure and Applied Chemistry, 4(1): 137-143

[33] Cheesbrough, M. (2000). District Laboratory Practice Manual in Tropical Countries Part 2. Cambridge University Press, Cambridge, 178-179. https://www.scirp.org/(S(351jmbntvnsjt1aadkposzje))/reference/ReferencesPapers.aspx?ReferenceID=118 1453.

[34] Giacometti, A., Cirioni, O., Schimizzi, A., Del Prete, M., Barchiesi, F., and D'errico, M. (2000). Epidemiology and microbiology of surgical wound infections. Journal of clinical Microbiology, 38(2): 918-22.

[35] Omeodu, S. I., Onyegeme-Okerenta, B. M., and Amakiri, A. P. (2017). Effect of delonix regia seed extract on some liver enzyme markers and electrolytes of alloxan induced diabetic rats. Journal of Pharmaceutical and Scientific Innovation, 6(2): 37-4.

[36] Mohammed, A., Adeshina, G. O., and Ibrahim, Y. K. E. (2013). Retrospective incidence of wound infections and antibiotic sensitivity pattern: A study conducted at the Aminu Kano Teaching Hospital, Kano, Nigeria. Int. J. Med. Med. Sci., 55: 60-66.

[37] Anaya, D. A. and Dellinger, E. P. (2006). Challenges in the prevention of surgical site infections. Infections in Medicine, 23: 12-126.

[38] Agbonlahor, D. E., Ehiaghe, J. I., Eremwanarue, O. A., Ehiaghe, A. F., and Oviasogie, F. E. (2018). A primal incrimination of Cedecea davisae with post-prostatectomy urinary tract infection in Nigeria. International Journal of Biological and Chemical Science, 12(2): 676-688.

[39] Ehiaghe, J. I., Nwobu, R. A. U., Ehiaghe, F. A., Agbakoba, N. R. and Agbonlahor, D. E. (2016). Plasmid Profiling of Multi- 
drug Resistant Bacteria Isolates from Surgical Site Infection in Nigeria. Am. J. Biotechnol. Mol. Sci., 5(1): 23-32.

[40] Trivedi, M. K., Branton, A., Trivedi, D., Nayak, G., and Gangwar, M. (2015). Bacterial identification using 16S rDNA gene sequencing and antibiogram analysis on biofield treated Pseudomonas fluorescens. Clin Med Biochem Open Access, 1: 101.

[41] Voravuthikunchai, S. P. and Kitpipit, L. (2003). Activities of crude extracts of Thai medicinal plants on methicillin-resistant Staphylococcus aureus. Journal of Clinical Microbiology and Infection, 9: 229-236.

[42] Tirado-Torres, D., Chan-Keb, C. A., Pérez-Balán, R. A., Ake-Canché, B., Gómez Solano, M. I., Aragón-Gastélum, J. L., Gómez-López, I., Aguirre-Crespo, F. J., López-Ramos, M. C., and Gutiérrez-Alcántara, E. J. (2019). Antimicrobial activity of Moringa oleifera against multidrug-resistant Staphylococcus aureus isolated from raw milk. Applied Ecology and Environmental Research, 17(1), pp. 587-599.

[43] Abadallah, M. S. and Ali, M. (2019). Antibacterial activity of Moringa oleifera leaf extracts against bacteria isolated from patients attending general Sani Abacha specialist hospital damaturu. Journal of Allied Pharmaceutical Sciences, 1(1): 61-66.

[44] Patel, P., Patel, N., Patel, D., Desai, S., and Meshram, D. (2014). Phytochemical analysis and antifungal activity of Moringa oleifera. Int J Pharm Sci., 6(5): 144-7.

[45] Arya, V., Thakur, N. M., and Kashyap, C. (2012). Preliminary Phytochemical Analysis of the Extracts of Psidium Leaves. J Pharmacogn Phytochem., 1: 1-5.

[46] Nweze, N. O. and Nwafor, F. I. (2014). Phytochemical, Proximate and Mineral Composition of Leaf Extracts of Moringa oleifera Lam. from Nsukka, South-Eastern Nigeria. IOSR Journal of Pharmacy and Biological Sciences, 9(I 1): 99-103.

[47] Kasolo, J. N., Bimenya, G. S., Ojok, L., Ochieng, J., and Ogwal-Okeng, J. W. (2010). Phytochemicals and uses of Moringa oleifera Leaves in Ugandan rural communities. Journal of Medicinal Plant Research, 4(9): 753-757.

[48] Oluduro, A. O. (2012). Evaluation of antimicrobial properties and nutritional potentials of Moringa oleifera Lam. leaf in South Western Nigeria. Malaysian Journal of Microbiology, 8(2): 59-67.

[49] Bamishaiye, E. I., Olayemi, F. F., Awagu, E. F., and Bamishaiye, O. M. (2011). Proximate and phytochemical composition of Moringa oleifera leaves at three stages of maturation. Advanced Journal of Food Science and Technology, 3(4): $233-237$.

[50] Nwozo, S. O., Ikpeme G. E., and Nwawuba, S. U. (2019). Functional Dietary Supplementation of Okara (Soybeans Residue) on Streptozotocin Induced Diabetes Mellitus in Male Wistar Rats. Global Journal of Medical Research: F Diseases, 19(5): 17-28.

[51] Elzein, M. F., Rani, B. A. M., Aklakur, M. D., Chanu, T. I., and Neelam, S. (2018). Qualitative and Quantitative Phytochemical Analysis of Moringa oleifera (Lam) Pods, International Journal of Current Microbiology and Applied Sciences, 7(5): 657-665.

[52] Gupta, M., Thakur, S., Sharma, A., and Gupta, S. (2013). Qualitative and Quantitative Analysis of Phytochemicals and Pharmacological Value of Some Dye Yielding Medicinal Plants. Orien. J. Chem., 29(2): 475-48.

[53] Ashwani, K. and Ashish, B. (2013). Comparative qualitative quantitative chemo-typic characterization among North Indian Tribulus terrestris. International Research Journal of Pharmacy, 3(6): 212-218.

[54] Sathya, V., Bharathidasan, S., TamilSelvi, N., Sophia, R., Ilakkiya, R., and Prabakaran, M. (2013). Quantitative, qualitative phytochemical analysis and in vitro antibacterial activity of Bauhinia tomentosa L. J. Nat. Prod. Plant Resour, 3(2): 31-36.

[55] Mishra, G., Singh, P., Verma, R., Kumar, S., Srivastav, S., Jha, K.K., and Khosa, R. L. (2011). Traditional uses, Phytochemistry and Pharmacological properties of Moringa oleifera plant: An overview. Der Pharmacia Lettre, 3(2): 141-164.

[56] Saadabi, A. M., Abu, M., and Zaid, I. E. (2011). An In vitro Antimicrobial Activity of Moringa oleifera L. Seed Extracts Against Different Groups of Microorganisms. AustraLian JournaL of Basic and Applied Sciences, 5(5): 129-134.

[57] Farooq, F., Rai, M., Tiwari, V., Khan, A. A., and Farooq, S. (2012). Medicinal properties of Moringa oleifera: An overview of promising healer. JournaL of MedicinaL PLants Research, 6(27): 4368-4374.

[58] Khesorn, N. (2009). Antibacterial activity of the capsules of Moringa oleifera Lam. (Moringaceae). Journal of Ethnopharmacology, 36: 233-237.

[59] WaIter, A., Samuel, W., Peter, A., and Joseph, A. (2011). Antibacterial activity of Moringa oleifera and Moringa stenopetala methanol and n-hexane seed extracts on bacteria implicated in water borne disease. African Journal of Microbiology Research, 5 (2): 153-157.

[60] Tiwari, P., Kumar, B., Kaur, M., Kaur, G., and Kaur, H. (2011). Phytochemical screening and extraction: A review. Internationale Pharmaceutica Sciencia, 1(1): 98-106.

[61] Akaneme, F. I. (2008). Identification and preliminary phytochemical analysis of herbs that can arrest threatened miscarriage in Orba and Nsukka towns of Enugu State. African Journal of Biotechnology, 7(1): 006-011.

[62] Amabye, T. G. and Tadess, F. M. (2016). Phytochemical and antibacterial activity of moringa oleifera available in the market of Mekelle. Journal of Analytical and Pharmaceutical Research, 2(1): 23-26.

[63] Xie, Y., Yang, W., Tang, F., Chen, X., and Ren, L. (2015). Antibacterial activities of flavonoids: Structure-activity relationship and mechanism. Current Medicinal Chemistry, 22(1): 132-149. 